\title{
Contamination Potential of an Urban Mine Tailings Deposit in Central Mexico -A Preliminary Estimation
}

\author{
Liliana Lizárraga-Mendiola1* ${ }^{*}$, Diana Elizabeth Ángeles-Chávez², Alberto Blanco-Piñón², \\ Màrius Ramírez-Cardona ${ }^{2}$, Francisco Javier Olguín-Coca ${ }^{1}$, \\ María del Refugio González-Sandoval ${ }^{1}$ \\ ${ }^{1}$ Academic Area of Engineering, Institute of Basic Sciences and Engineering, \\ Autonomous University of the State of Hidalgo, Pachuca, Mexico \\ ${ }^{2}$ Academic Area of Earth and Materials Sciences, Institute of Basic Sciences and Engineering, \\ Autonomous University of the State of Hidalgo, Pachuca, Mexico \\ Email: ${ }^{*}$ lililga.Im@gmail.com
}

Received 21 January 2014; revised 15 February 2014; accepted 11 March 2014

Copyright (C) 2014 by authors and Scientific Research Publishing Inc.

This work is licensed under the Creative Commons Attribution International License (CC BY). http://creativecommons.org/licenses/by/4.0/

(c) (i) Open Access

\section{Abstract}

This study consisted of a geochemical analysis of the Dos Carlos tailings' deposit located in the Mining District of Pachuca-Real del Monte in the state of Hidalgo, Central Mexico. The goal of the study was to determine the potential effects of this deposit on the environment and health of the population of the metropolitan area of Pachuca. Sampling was conducted from the top to the base of two raised sections at opposite ends of the deposit, and macroscopic features (profiles A and B) of these deposits were evaluated. Subsequently, mineralogical analyses of the collected samples were performed using $X$-ray diffraction and physico-chemical analysis of the leachates. The results were compared with the maximum permissible limits established by different national and international standards for drinking water and hazardous waste. In addition, geochemical modeling was conducted using PHREEQC to calculate the distribution of aqueous species, ionic activities and saturation indices. Of the 35 samples of leachate analyzed for profile $A$, two samples had two to nearly three times the national permissible maximum limits of $\mathrm{Cr}^{6+}$ in drinking water, four samples had $\mathrm{NO}_{3}^{-}$levels that exceeded these limits and 19 samples had $\mathrm{NO}_{2}^{-}$levels that exceeded these limits. Of the 10 samples analyzed from profile $\mathrm{B}$, six samples had $\mathrm{NO}_{3}^{-}$levels that were up to fourteen times higher than the limit for human consumption, and six samples had levels of $\mathrm{NO}_{2}^{-}$that were up to 28 times higher than the permissible limit. The predominant minerals found in the Dos Carlos tailings' deposit were quartz, feldspar, clay from the kaolinite group, and calcite and or-

\footnotetext{
"Corresponding author.
} 
thopyroxene (enstatite-ferrosilite series). The samples from profile $A$ indicated that minerals containing $\mathrm{Ag}_{\text {metallic, }} \mathrm{Cd}^{2+}, \mathrm{Cu}^{+}, \mathrm{Ni}^{2+}, \mathrm{Pb}^{2+}$ and $\mathrm{Zn}^{2+}$ were dissolved, whereas minerals containing $\mathrm{Fe}_{\text {total, }}$ $\mathrm{Mn}^{2+}, \mathrm{Pb}(\mathrm{OH})_{3}$ and $\mathrm{Zn}^{2+}$ were in a state of precipitation. In profile $\mathrm{B}$, the dissolution of minerals containing $\mathrm{Ag}_{\text {metallic, }} \mathrm{As}^{5+}, \mathrm{Cd}^{2+}, \mathrm{Cu}^{+}, \mathrm{Mn}^{2+}, \mathrm{Ni}^{2+}, \mathrm{Pb}^{2+}$ and $\mathrm{Zn}^{2+}$ was observed only in a superficial sample, whereas $\mathrm{Ag}_{\text {metallic, }} \mathrm{Fe}_{\text {total, }}, \mathrm{Mn}^{2+}, \mathrm{Pb}_{3}\left(\mathrm{PO}_{4}\right)_{2}$ and $\mathrm{PbHPO}_{4}$ were found in a precipitated state. The above-mentioned species that occurred in a state of dissolution pose an environmental threat to the groundwater in the study area; indeed, the tailings' deposit provides the conditions necessary for these minerals to leach and infiltrate into the subsoil or be transported by wind, deposited in the soil of the surrounding area and inhaled by the nearby population, potentially compromising respiratory health.

\section{Keywords}

\section{Contamination; Dos Carlos Tailings; Mining District Pachuca-Real del Monte}

\section{Introduction}

In Mexico, one of the major byproducts of mining activity is the generation of millions of tons of tailings or slurries. Some mining sites in the country have had produced tailings with environmental impacts, such as those located in the Mexican localities of Taxco, Guerrero [1]-[3]; Guanajuato, Guanajuato [4]-[7]; Santa Bárbara, Chihuahua [8] and Tizapa, Estado de México [9]-[11]. However, there are many sites where the source of contamination from tailing deposits is not obvious. One example is the tailings from the mining unit of Charcas, San Luis Potosí, which does not represent potential generators of acidity and does not contain soluble toxic elements; therefore, it is not considered hazardous [12].

The state of Hidalgo, an area with significant environmental problems, contains mining waste from the Zimapan district. The waste from this district is classified as dangerous because of its toxicity; in particular, even in stable forms, the arsenic content of the waste can contaminate the environment [13]. In the city of Pachuca, the accumulation of tailings in the urban area began in 1912 by order of the Department of Mining of the Secretariat of Industry and Trade [14]; this order was aimed at storing mining waste until techniques to recover the silver contained within the waste could be improved [15]. The Dos Carlos tailings' deposit began in response to this order. In 1959, this deposit contained approximately 55 million tons of waste [16]. Forty-seven million tons of these tailings were produced by the cyanidation of minerals from all parts of the mining district; eight million tons came from the only flotation plant of the Mining District of Pachuca-Real del Monte [17]. To date, the tailing deposits of the district have been investigated for a variety of purposes [18] [19]; however, few investigations have evaluated the individual deposits for environmental purposes. In this context, this paper presents a preliminary investigation of the contamination potential that the Dos Carlos tailings' deposit of the Mining District of Pachuca-Real del Monte in the state of Hidalgo presents to the environment and the health of the surrounding population.

\section{Description of the Study Area}

\subsection{Location}

The tailings deposit known as Dos Carlos is located at the coordinates $20^{\circ} 06^{\prime} 20^{\prime \prime}$ latitude north and $98^{\circ} 42^{\prime} 46.8^{\prime \prime}$ longitude west to the north of the municipality of Pachuca in the state of Hidalgo (Figure 1). The deposit has an elevation of 2437 meters above sea level (masl) [20].

\subsection{Climate}

According to the climatic classification of [21] and the modified classification of [22], the city of Pachuca has a dry climate of subtype BS1k'w(w)(I'). The rainy season usually occurs from April to September, and maximum average precipitation levels (203.9 mm) occur in the month of May; however, in some years, the rainy season can begin in March and extend through late October or early November. In general, Pachuca has a temperate 


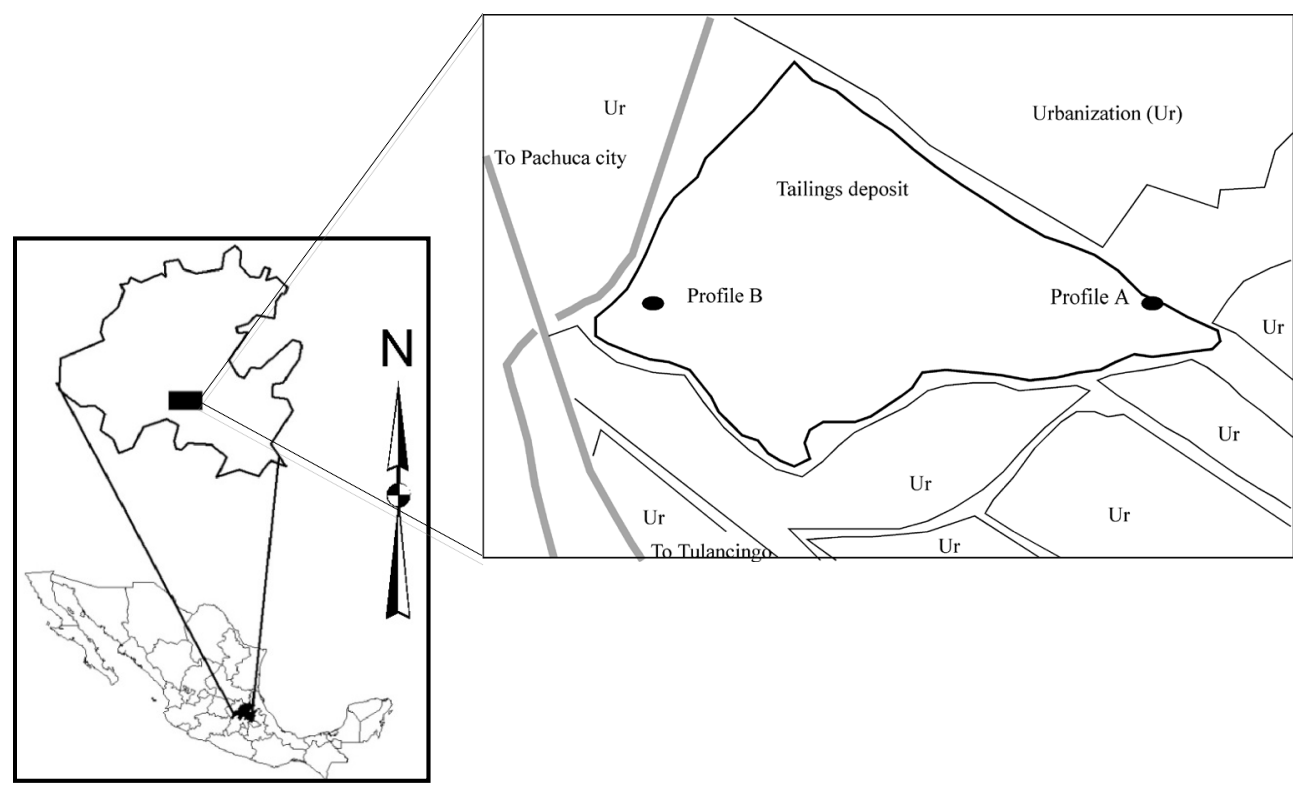

Figure 1. Location of the study area (No scale).

climate. Its annual average temperature oscillates between $11.3^{\circ} \mathrm{C}$ and $16.6^{\circ} \mathrm{C}$. The highest temperatures occur in April (maximum temperatures of $28.8^{\circ} \mathrm{C}$ ) and the lowest temperatures occur in January (minimum temperatures of $-3^{\circ} \mathrm{C}$ ). Most of the year is dominated by winds that blow in a north-south and northeast-southwesterly direction and reach an average speed of 22 to $24 \mathrm{~m} / \mathrm{s}$ [23].

\subsection{Description of the District and Tailings Deposit}

Pachuca-Real del Monte is one of the oldest silver-producing mining districts of Mexico. It is located in Sierra de Pachuca in the metallogenic province of the Mexican Neovolcanic Axis. The site is characterized by its epithermal polymetallic deposits of silver, lead, zinc, copper and gold [24]. Hundreds of productive veins are scattered along a surface with an area of $70 \mathrm{~km}^{2}$; this area has been exploited for more than 500 years and has yielded 40 million $\mathrm{kg}$ of silver from a total of 100 million metric tons of ore with $1 \%$ of total sulfides. These veins have a series of calc-alkaline volcanic rocks from the Oligocene-Miocene age (Figure 2) with a thickness of $2700 \mathrm{~m}$ [25].

The tailings deposit, which is surrounded by housing complexes, is located in the northern part of the city, approximately 10 meters from the Sosa riverbed. Because it is directly exposed to the weather conditions, the mining waste deposit site was selected according to the area and volume of the site and its state of neglect and inactivity. We found no indication that the site is monitored, and no studies have been performed to analyze the behavior of the chemical speciation of the minerals of the site; consequently, the environmental contamination potential of these tailings and their effects on the health of the population are unknown.

\section{Methods}

\subsection{Field Work}

Two raised sections at opposite ends of the Dos Carlos tailings deposit were described based on the specifications established by the NOM-141-SEMARNAT-2003 [26], the NMX-AA-132-SCFI-2005 [27] and the NOM-052-SEMARNAT-2006 [28]. The selection criterion was that the deposit has had several periods of deposition, therefore, the profiles selected represent the oldest and most recent stage of mineral processing. The northeast end (profile A), which is approximately $5.32 \mathrm{~m}$ high with respect to the natural terrain, contains the most recently deposited tailings (deposited during the 1980s); the southwestern end (profile B), which is approximately $7 \mathrm{~m}$ high, contains the older tailings deposited in the 1950s (Figure 1). Macroscopic characteristics such as the thickness of the layer or stratum, particle size, color and presence of oxidation were described in both sections (Tables 1 (a) and (b)). 


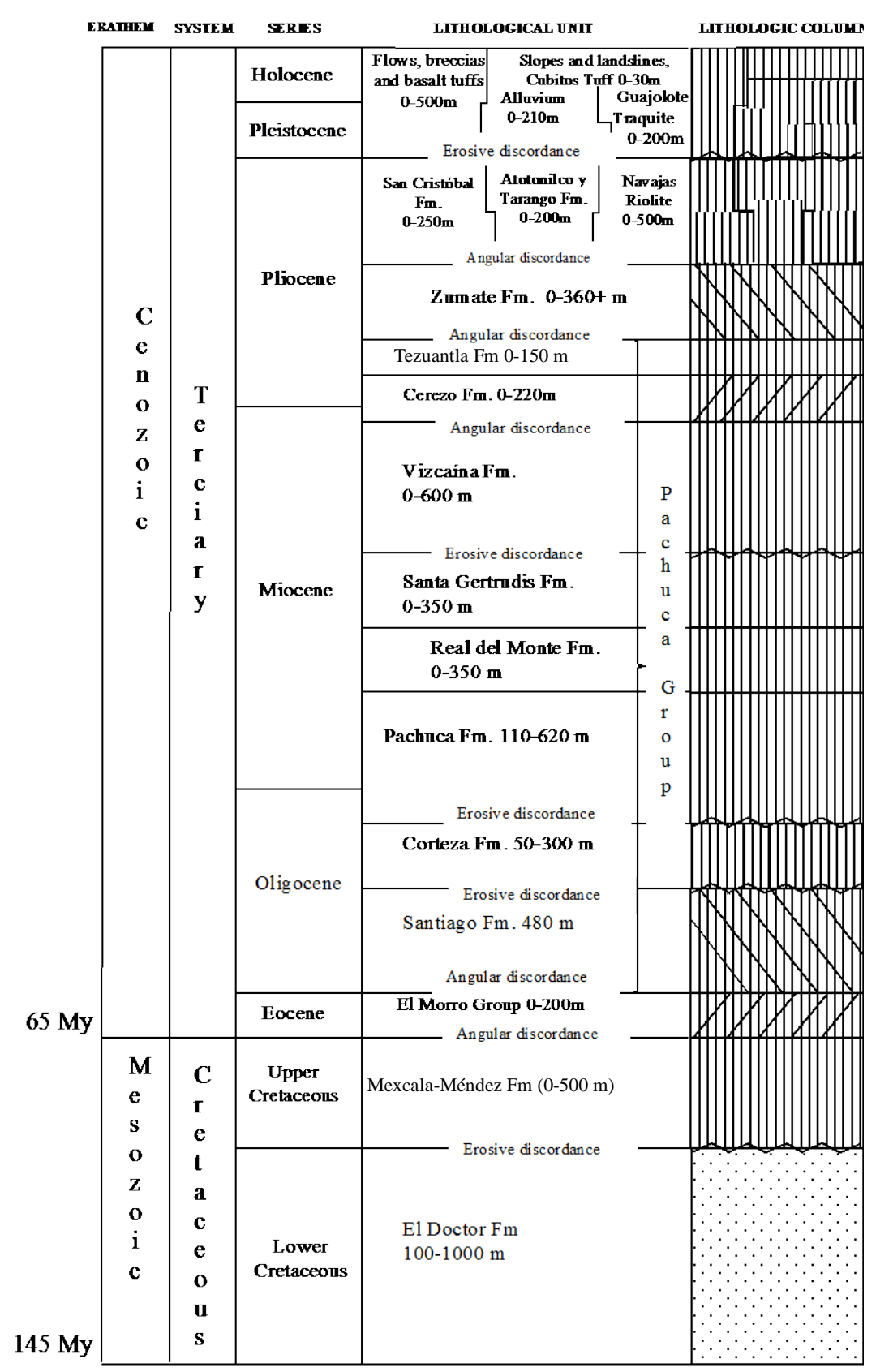

Figure 2. Stratigraphic column of the Mining District Pachuca-Real del Monte. No scale (Edited from [17]).

A total of 45 samples were collected from the top to the base of the studied sections based on changes in the different aforementioned macroscopic characteristics (35 from profile A and 10 from profile B). The collected samples were sieved (mesh \#60) to remove plant debris and non-tailing rock fragments. Subsequently, the samples were weighed to determine their total weight in grams, placed in pre-labeled polyethylene bags and transported to the Environmental Geology laboratory of the Academic Area of Earth and Material Sciences of the Autonomous University of the state of Hidalgo for analysis.

\subsection{Laboratory Work}

The following parameters were evaluated in the leachates: a) percent humidity, b) physical parameters such as 
Table 1. (a) Macroscopic characteristics of leachates in profile A. (b) Macroscopic characteristics of profile B.

(a)

\begin{tabular}{|c|c|c|c|}
\hline Sample & Stratum thickness (cm) & Depth (cm) & Macroscopic characteristics \\
\hline $1 \mathrm{~A}$ & 110 & $0-110$ & $\begin{array}{l}\text { Loose material with colors ranging from dark brown to orange, } \\
\text { presence of weathering and plant roots. Represents the top of the profile. }\end{array}$ \\
\hline $2 \mathrm{~A}$ & 5 & 115 & Black coloration \\
\hline $3 \mathrm{~A}$ & 24 & 139 & Silty, dark brown to gray \\
\hline $4 \mathrm{~A}$ & 1 & 140 & Sandy, light gray \\
\hline $5 \mathrm{~A}$ & 16 & 156 & Silty toward the base and at the top, dark brown; sandy in the center, gray \\
\hline $6 \mathrm{~A}$ & 1 & 157 & Sandy, dark gray \\
\hline $7 \mathrm{~A}$ & 3 & 160 & Silty, dark to light brown \\
\hline $8 \mathrm{~A}$ & 4 & 164 & Sandy, light gray \\
\hline $9 \mathrm{~A}$ & 25 & 189 & Intercalated layers of sand and dark brown silt \\
\hline $10 \mathrm{~A}$ & 5 & 194 & Sandy, light gray \\
\hline $11 \mathrm{~A}$ & 20 & 214 & Silty, light to dark brown \\
\hline $12 \mathrm{~A}$ & 4 & 218 & Sandy, dark gray with oxidation stains \\
\hline $13 \mathrm{~A}$ & 3.5 & 221.5 & Sandy, light to dark gray \\
\hline $13 A^{\prime}$ & 4 & 222 & $\begin{array}{l}\text { This sample comes from the same layer as sample 13A. It has the same texture } \\
\text { and coloration; in addition, reddish to orange oxidation is present. }\end{array}$ \\
\hline $14 \mathrm{~A}$ & 12 & 233.5 & Silty, light brown to dark brown \\
\hline $15 \mathrm{~A}$ & 2 & 235.5 & Sandy, light gray to dark gray \\
\hline $16 \mathrm{~A}$ & 15 & 250.5 & Silty, light brown to dark brown \\
\hline $17 \mathrm{~A}$ & 7 & 257.5 & Sandy, very fine texture, light gray color, very compact \\
\hline $18 \mathrm{~A}$ & 17 & 274.5 & Silty, light brown, very compact \\
\hline $19 \mathrm{~A}$ & 13 & 287.5 & Intercalated layers of sand and silt, light gray to light brown \\
\hline $20 \mathrm{~A}$ & 18 & 305.5 & Silty, light brown with sandy intercalated layers \\
\hline $21 \mathrm{~A}$ & 9 & 314.5 & Silty, light brown, very compact \\
\hline $22 \mathrm{~A}$ & 16 & 330.5 & Sandy, light gray; in the center, there is a light brown silt layer $(1.5 \mathrm{~cm})$ \\
\hline $23 \mathrm{~A}$ & 37 & 367.5 & Silty, light brown with small alternating layers of light gray sand $(3-4 \mathrm{~cm})$ \\
\hline $24 \mathrm{~A}$ & 19 & 386.5 & $\begin{array}{c}\text { Alternating layers of sand and silt, dark gray to light gray; } \\
\text { each sublayer is } 3 \text { to } 4 \mathrm{~cm} \text { thick }\end{array}$ \\
\hline $25 \mathrm{~A}$ & 33.5 & 420 & $\begin{array}{l}\text { Sandy with alternating layers of silt and very fine light brown to } \\
\text { light gray sand with oxide lenses } 1 \text { to } 2 \mathrm{~cm} \text { thick }\end{array}$ \\
\hline $\mathrm{Q}$ & 4 & 424 & Sandy, light gray, slightly compact \\
\hline $27 \mathrm{~A}$ & 7 & 431 & Silty, dark brown with black nodules, very compact, moist \\
\hline $28 \mathrm{~A}$ & 5.5 & 436.5 & Sandy, light gray, very loose material \\
\hline $29 \mathrm{~A}$ & 19.5 & 456 & $\begin{array}{c}\text { Silty, dark brown, with a layer of medium-grain dark } \\
\text { gray sand with small black spots }\end{array}$ \\
\hline $30 \mathrm{~A}$ & 22.5 & 478.5 & $\begin{array}{l}\text { At the top, there is a layer of medium-grained light gray sand with a sheet } \\
\text { of nodules. The center is light brown and silty with oxide lenses. At the base, } \\
\text { there is a layer of fine to medium sand with oxide lenses }\end{array}$ \\
\hline $31 \mathrm{~A}$ & 32 & 510.5 & $\begin{array}{l}\text { Clay with alternating cream to very light brown layers; the last 9.1-cm-thick } \\
\text { layer from the base consists of alternating layers of cream-colored clay and } \\
\text { dark material with small oxide lenses }\end{array}$ \\
\hline $32 \mathrm{~A}$ & 10 & 520.5 & Silty, dark brown, very compact \\
\hline $33 \mathrm{~A}$ & 11 & 531.5 & Fine sand, light gray at the top and base and dark gray in the center \\
\hline
\end{tabular}


(b)

\begin{tabular}{|c|c|c|}
\hline \# of escarpment & Sample & Macroscopic characteristics \\
\hline 1 & 10B & $\begin{array}{l}\text { Clay with thin layers of fine light gray sand. Has a horizontal fracture filled } \\
\text { with fine light gray sand. Presence of vegetation on the top of this escarpment. }\end{array}$ \\
\hline 2 & 9B & $\begin{array}{l}\text { Clay, dark to light brown, moist, very compact } \\
\text { except on the top where the material is soft }\end{array}$ \\
\hline \multirow{2}{*}{3} & 8B & $\begin{array}{l}\text { Clayey, with intercalating dark and light brown layers, } \\
\text { presence of small reddish surfaces }\end{array}$ \\
\hline & 7B & $\begin{array}{l}\text { Very narrow intercalating light and dark brown layers; } \\
\text { the sublayers show surface runoff }\end{array}$ \\
\hline \multirow{3}{*}{4} & $6 \mathrm{~B}$ & $\begin{array}{l}\text { Intercalating layers of clay with very fine dark to cream brown sand, } \\
\text { slightly compact, presence of small red surfaces, dry and rough }\end{array}$ \\
\hline & $5 B$ & Clay, light brown, with one end cradled horizontally \\
\hline & 4B & $\begin{array}{l}\text { Has the appearance of a clayey dark brown conglomerate; } \\
\text { toward the top, small reddish surfaces with white edges }\end{array}$ \\
\hline \multirow{3}{*}{5} & 3B & $\begin{array}{l}\text { Toward the base, light brown clay; toward the top, } \\
\text { fine, light gray sand with black spots, very compact }\end{array}$ \\
\hline & 2B & Sandy, fine grain, with yellow to light reddish brown oxidation \\
\hline & 1B & $\begin{array}{l}\text { Intercalating layers of clay and fine sand at the base; the center is made up of } \\
\text { reddish clay; at the top, intercalating layers of clay and fine sand are found. }\end{array}$ \\
\hline
\end{tabular}

temperature, $\mathrm{pH}$, electrical conductivity (EC), redox potential (Eh) and dissolved solids (measured with electrodes, models HI98120 and HI98129-Hanna ${ }^{\circledR}$ instruments, USA-), c) levels of ions such as $\mathrm{Cr}^{6+}, \mathrm{Cu}^{+}, \mathrm{NO}_{3}^{-}$, $\mathrm{NO}_{2}^{-}, \mathrm{PO}_{4}^{3-}, \mathrm{P}^{+}, \mathrm{SiO}_{2}$ and $\mathrm{Zn}^{2+}$, d) mineralogical contents using X-ray diffraction, e) geochemical modeling, and f) average daily dose.

\subsubsection{Percent Humidity}

To determine the percent humidity, the samples were sieved and weighed in the field $(\mathrm{Ph})$ and desiccated in an ORL-V (O.R.L., USA) oven for 24 hours at $150^{\circ} \mathrm{C}$ to eliminate the existing moisture. The samples were then weighed again (Ps). The percentage of total humidity (\%th) was calculated:

$$
\% \text { th }=[(\mathrm{Ph}-\mathrm{Ps}) / \mathrm{Ph}] \times 100
$$

\subsubsection{Physical Parameters and Levels of Ions}

Parameters such as temperature, dissolved solids, $\mathrm{pH}$ and electrical conductivity were evaluated with a Combo $\mathrm{pH}$ and EC electrode, model HI98129 (-Hanna ${ }^{\circledR}$ instruments, USA), that was previously calibrated with reference buffers ( $\mathrm{pH} 4.01 \pm 0.01$ at $25^{\circ} \mathrm{C}$ and $\mathrm{pH} 7.00 \pm 0.01$ at $25^{\circ} \mathrm{C}$ ). The oxidation-reduction potential (ORP or Eh) was measured under the same conditions used for the $\mathrm{pH}$ and EC with a Hanna Instruments ORP potentiometer, model HI 98120 calibrated by the manufacturer (-Hanna ${ }^{\circledR}$ instruments, USA).

Subsequently, the samples were prepared to evaluate the above-mentioned physical and chemical parameters: $100 \mathrm{~g}$ of tailings were added to $500 \mathrm{ml}$ of distilled water and left for 48 hours. Three vials of distilled water without tailings were used as controls in all analyses. The analytical quality was calibrated using samples of certified High Purity Standards. Detection limits were as follows: $\mathrm{Cr}^{6+}(0.005 \mathrm{mg} / \mathrm{L}), \mathrm{Cu}^{+}(0.001 \mathrm{mg} / \mathrm{L}), \mathrm{NO}_{3}^{-} \quad(0.5$ $\mathrm{mg} / \mathrm{L}), \quad \mathrm{NO}_{2}^{-}(0.02 \mathrm{mg} / \mathrm{L}), \mathrm{PO}_{4}^{3-}(0.04 \mathrm{mg} / \mathrm{L}), \mathrm{P}^{+}(0.3 \mathrm{mg} / \mathrm{L}), \mathrm{SiO}_{2}(0.03 \mathrm{mg} / \mathrm{L})$ and $\mathrm{Zn}^{2+}(0.003 \mathrm{mg} / \mathrm{L})$; these limits were determined using a multiparametric photometer, model HI83206 (-Hanna ${ }^{\circledR}$ instruments, USA). The error in the ionic balance was verified to be less than $10 \%$.

The values obtained in the leachate analysis were compared with the maximum permissible limits (MPL) a) for drinking water established by the Mexican standards NOM-127-SSA1-1994 [29], by the United States [30] and by the World Health Organization [31]; b) for water discharged into rivers and artificial reservoirs established by the NOM-001-SEMARNAT-1996 [32] and c) for the classification of waste considered hazardous to the environment because of its toxicity according to the NOM-052-SEMARNAT-2005 [28]. 


\subsubsection{Mineralogical Contents}

The mineralogical analysis was conducted using X-ray diffraction (XRD). Fourteen samples with oxidation or high concentrations of $\mathrm{Cr}^{6+}, \mathrm{Cu}^{+}, \mathrm{SiO}_{2}$ and/or $\mathrm{Zn}^{2+}$ were selected from each of the samples; ten of these samples corresponded to profile A and four to profile B. The analyses were conducted at the Department of Geochemistry of the Geological Institute of the National Autonomous University of Mexico. The diffractograms were obtained with a Shimadzu XRD-6000 diffractometer (Shimadzu Corp., USA) equipped with a monochromator and copper tube. Two grams were required for each sample. The samples were milled with an agate mortar and analyzed in an aluminum sample holder (non-oriented fraction) at an angle of $2 \theta$ with intervals ranging from $4^{\circ}$ to $70^{\circ}$ and velocities of $2^{\circ}$ /minute.

\subsubsection{Geochemical Modeling}

The PHREEQC software for Windows (version 2.18.5570) was used for environmental geochemical modeling [33]. The speciation code WATEQ4F Version 2.63 [34] was selected to calculate the distribution of aqueous species, ionic activities and saturation indices based on the values of temperature, $\mathrm{pH}$, Eh, and ionic concentrations determined in the laboratory. Using this simulation software, it was possible to analyze trends in dissolution, precipitation or equilibrium of a mineral in contact with water. The activity coefficients were obtained with the Debye-Huckel or Davis equations depending on the ionic strength of the solution [35]. The product of ionic activity (PIA) is used to calculate the saturation index (SI):

$$
\mathrm{SI}=\log (\mathrm{PIA} / \mathrm{Ksp}),
$$

where Ksp is the solubility constant. With these data, it was possible to determine the tendency of water to dissolve a mineral $(\mathrm{SI}<0)$, precipitate $(\mathrm{SI}>0)$ or maintain equilibrium $(\mathrm{SI}=0)$.

\subsubsection{Average Daily Dose}

The risk to the surrounding population associated with the oral ingestion of $\mathrm{Cr}^{6+}$ was measured and was calculated as follows:

$$
\mathrm{ADD}=(\mathrm{C} \times \mathrm{IRw} \times \mathrm{ED} \times \mathrm{EF}) /(\mathrm{BW} \times \mathrm{AT} \times 365)
$$

The average daily dose (ADD) specifies the amount of contaminant that is ingested by a Mexican adult with an average weight [36]. C is the concentration of the contaminant $\left(\mathrm{Cr}^{6+}\right.$, in this study $\left.\mathrm{mg} / \mathrm{L}\right)$, IRw is the ingestion rate per unit time (L/day), ED is the exposure duration (years), EF is the exposure frequency (days/year), BW is the body weight of the receptor (kg), and AT is the averaging time (years), equal to the life expectancy, and 365 is the conversion factor from year to days.

\section{Results}

\subsection{Physical Characteristics of Tailings}

Profiles A and B both have materials with a heterogeneous granulometry. Profile A consists of a 5.32-m-thick material composed of particles with sizes varying from fine sand to silt fractions, with the fine sand fraction being predominant (Tables 1(a) and (b)). The deposits are arranged in horizons with Munsell scale colors of light brown (6/3 7.5YR) and light gray (6/2 7.5YR) and thicknesses that vary from 1 to $37 \mathrm{~cm}$; one of the horizons at the top has a peak thickness of $110 \mathrm{~cm}$. In addition, the tailings have intercalated slightly darker (5/3 7.5YR) horizons with thicknesses ranging from 1 to $5 \mathrm{~cm}$. The coloration is not associated with granulometry. Occasionally, profile A has 4-cm (12A) and 33.5-cm-thick (25A) gray (7/1 7.5YR) horizons with yellowish brown (7/8 10YR) and reddish brown (5/8 7.5YR) bands that were considered to be iron oxide. Profile B has the same granulometric characteristics and colorations as profile A; however, the reddish iron oxide layers (5/8 7.5YR) are more frequently encountered in profile B than in profile A. Toward the top of the deposit and distributed throughout, a 3-m-thick layer of intermediate gray color (4/1 5Y) that corresponds to a sandy loam soil type is found. On this soil horizon, vegetation from the families Cactaceae, Asteraceae, Poaceae, Leguminosae, Chenopodiaceae, Solanaceae and Cruciferae and the species Brickelia veronicifolia, Zaluzania triloba, Solanum elaeagnifolium, Stipa tenuissima, Bouteloua curtipendula, Haplopappus venetus and Cinodon dactylon can be found [37].

In both profiles $\mathrm{A}$ and $\mathrm{B}$, the humidity content varies from $1 \%$ to $15 \%$. The strata with the highest percent 
humidity in both profiles consist mainly of sand-sized particles that easily lose moisture and are generally not observed in an oxidation state; oxidation was detected in both of the strata consisting of fine-textured particles of silt and/or clay (Tables 1 (a) and (b)).

Variations in potential of hydrogen $(\mathrm{pH})$ were observed within each profile. In profile A, the $\mathrm{pH}$ varies from 7 to 7.64; in profile $\mathrm{B}$, the $\mathrm{pH}$ varies from 7.27 to 7.85 . In both cases, the slightly acidic medium becomes slightly alkaline. Additionally, horizons with $\mathrm{pH}$ values of 6 occasionally exhibit reddish to brown sheets with thicknesses of only a few millimeters, which indicate the oxidation of Fe sulfides; in contrast, these sheets are absent in the horizons with $\mathrm{pH}$ values greater than 6 (Tables 2(a) and (b)).

\subsection{Chemistry of the Tailings}

The results of the chemical analysis of the leachates $\left(\mathrm{Cr}^{6+}, \mathrm{Cu}^{+}, \mathrm{NO}_{3}^{-}, \mathrm{NO}_{2}^{-}, \mathrm{PO}_{4}^{3-}, \mathrm{P}^{+}, \mathrm{SiO}_{2}\right.$ and $\left.\mathrm{Zn}^{2+}\right)$ for profiles A and B are summarized in Tables 2(a) and (b), respectively. The levels in the leachates were compared to the national [29] and international [30] [31] environmental standards for drinking water and for water discharged into rivers and artificial reservoirs [32]. These levels were also examined in the context of the classification of hazardous waste considered toxic to the environment [28] to evaluate whether the infiltration of these leachates into the ground water poses a risk to inhabitants consuming the drinking water. Of the 35 leachates samples analyzed for profile A, only samples 2A and 33A, had levels of $\mathrm{Cr}^{6+}$ (maximum $=0.014 \mathrm{mg} / \mathrm{L}$; average $=0 \mathrm{mg} / \mathrm{L}$ ) that were, respectively, twice- and almost three-fold higher than the maximum permissible limit (MPL) established for drinking water by [29]-[31]. Samples 26A, 29A, 31A and 32A had levels of $\mathrm{NO}_{3}^{-}$ (maximum $=12.85 \mathrm{mg} / \mathrm{L}$; average $=4.25 \mathrm{mg} / \mathrm{L}$ ) that slightly exceeded the MPLs established by the standards [29] [30]. Samples 1A, 3A, 5A, 10A, 11A, 12A, 16A, 17A, 18A, 19A, 20A, 21A, 23A, 25A, 26A, 27A, 29A, 31A and 32A had $\mathrm{NO}_{2}^{-}$levels (maximum $=1.57 \mathrm{mg} / \mathrm{L}$; average $=0.30 \mathrm{mg} / \mathrm{L}$ ) that exceeded the MPL [29] [30].

Of the 10 samples analyzed in profile $\mathrm{B}$, samples $1 \mathrm{~B}, 2 \mathrm{~B}, 3 \mathrm{~B}, 4 \mathrm{~B}, 7 \mathrm{~B}$ and $8 \mathrm{~B}$ had $\mathrm{NO}_{3}^{-}$levels (maximum = $146.19 \mathrm{mg} / \mathrm{L}$; average $=38.96 \mathrm{mg} / \mathrm{L}$ ) that were 14 times higher than the MPL for drinking water established by the [29] [30] and three times higher than the MPL established by the [31]. Samples 1B, 2B, 3B, 6B, 9B and 10B had levels of $\mathrm{NO}_{2}^{-}$(maximum $=1.57 \mathrm{mg} / \mathrm{L}$; average $=0.48 \mathrm{mg} / \mathrm{L}$ ) that were up to 28 times higher than the MPLs established by the [29] and slightly higher than the MPL established by the [30].

Table 2. (a) Concentrations from the chemical analysis of Profile A. (b) Concentrations from the chemical analyses of Profile B.

(a)

\begin{tabular}{cccccccccccc}
\hline & $\mathbf{p H}$ & $\mathbf{E h}$ & $\mathbf{E . C}$. & $\mathbf{C r}^{6+}$ & $\mathbf{C u}^{+}$ & $\mathbf{N O}_{3}^{-}$ & $\mathbf{N O}_{2}^{-}$ & $\mathbf{P O}_{4}^{3-}$ & $\mathbf{P}^{+}$ & $\mathbf{S i O}_{2}$ & $\mathbf{Z n}^{2+}$ \\
\hline & & $\mathrm{mV}$ & $\mu \mathrm{S} / \mathrm{cm}$ & & & & & $\mathrm{mg} / \mathrm{L}$ & & & \\
\hline Maximum & 7.64 & 217 & 1102.9 & 0.075 & 5.1067 & 146.19 & 1.406 & 3.575 & 1.3 & 2.2 & 1.96 \\
Minimum & 7 & 175 & 723.2 & 0 & 0 & 0 & 0 & 0.74 & 0 & 0 & 0 \\
Average & 7.375 & 193.5 & 938.73 & 0.0162 & 1.0791 & 56.81 & 0.48 & 1.91 & 0.64 & 1.74 & 0.32 \\
Std. Dev. & 0.17 & 13.48 & 0.17 & 0.0231 & 1.479 & 63.13 & 0.45 & 0.84 & 0.47 & 0.65 & 0.59 \\
\hline
\end{tabular}

(b)

\begin{tabular}{cccccccccccc}
\hline & $\mathbf{p H}$ & $\mathbf{E h}$ & $\mathbf{E . C}$. & $\mathbf{C r}^{6+}$ & $\mathbf{C u}^{+}$ & $\mathbf{N O}_{3}^{-}$ & $\mathbf{N O}_{2}^{-}$ & $\mathbf{P O}_{4}^{3-}$ & $\mathbf{P}^{+}$ & $\mathbf{S i O}_{2}$ & $\mathbf{Z n}^{2+}$ \\
\hline & & $\mathrm{mV}$ & $\mu \mathrm{S} / \mathrm{cm}$ & & & & & $\mathrm{mg} / \mathrm{L}$ & & & \\
\hline Maximum & 7.85 & 2248.92 & 270 & 0.014 & 3.675 & 12.84 & 1.57 & 5.08 & 3 & 2.75 & 1.93 \\
Minimum & 7.27 & 237.5 & 182 & 0 & 0 & 0 & 0 & 0 & 0 & 0 & 0 \\
Average & 7.568 & 1165.3 & 228.02 & 0.00261 & 0.491 & 4.14 & 0.30 & 1.81 & 0.46 & 2.05 & 0.32 \\
Std. Dev. & 0.162 & 542.91 & 22.86 & 0.00381 & 0.669 & 3.90 & 0.36 & 1.37 & 0.66 & 0.51 & 0.53 \\
\hline
\end{tabular}




\subsection{Mineralogical Analyses Using XRD}

The mineralogical variability of the samples of tailings was minimal (Table 3). The predominant minerals and mineralogical groups were quartz, feldspar, clays of the kaolinite group (to $7.3 \AA$ ), as well as calcite and orthopyroxene (enstatite-ferrosilite series). Phase identification was performed using the PDF-2 database of the International Center for Diffraction Data (ICDD) with the program Jade v.5. The Powder Diffraction File (PDF) patterns associated with peak identification were 00-019-0002, 00-046-1045, 00-014-0164, 00-047-1743 and 00-019-0607, which correspond to orthoclase, quartz, kaolinite-1 $\AA$, calcite and ferrosilite, respectively. The orthoclase pattern was associated with potassium feldspars, and ferrosilite was associated with a mineral of the enstatite-ferrosilite series. The adjustment process of the diffractometer allowed for refinement of the unit cell parameters. Phase quantification was carried out using the Reference Intensity Ratio (RIR) method [38].

In profile A, high concentrations of quartz were found in all samples $(77.3 \%-91.79 \%)$, followed by orthoclase $(4.28 \%-20.5 \%)$ and kaolinite $(2.2 \%-10.08 \%)$; calcite $(0.84 \%-5.10 \%)$ was found at a depth of $250.5 \mathrm{~cm}$, and ferrosilite $(5.5 \%-8.9 \%)$ was found only in the first $115 \mathrm{~cm}$ of depth. In profile B, quartz, orthoclase and kaolinite were present in the four selected samples $(5.34 \%-19.53 \%$, $9.5 \%-27.2 \%$, and $58 \%-76.5 \%$, respectively); calcite and ferrosilite were only found in one surface level sample (1.54\% and $3.4 \%$, respectively).

\subsection{Mineral Speciation and Geochemical Modeling}

The results of the selected samples from profiles A and B are shown in Figure 3. In profile A, geochemical modeling showed that minerals containing $\mathrm{Ag}_{\text {metallic }}, \mathrm{Cd}^{2+}, \mathrm{Cu}^{+}, \mathrm{Ni}^{2+}, \mathrm{Pb}^{2+}$ and $\mathrm{Zn}^{2+}$ were dissolved, whereas minerals containing $\mathrm{Fe}^{3+}, \mathrm{Mn}^{2+}, \mathrm{Pb}(\mathrm{OH})_{3}$ and $\mathrm{Zn}^{2+}$ were in a state of precipitation. In the case of profile $\mathrm{B}$, minerals that contain $\mathrm{Ag}_{\text {metallic }}, \mathrm{As}^{5+}, \mathrm{Cd}^{2+}, \mathrm{Cu}^{+}, \mathrm{Mn}^{2+}, \mathrm{Ni}^{2+}$ and $\mathrm{Pb}^{2+}$ were dissolved, and dissolved $\mathrm{Zn}^{2+}$ was only found in a surface sample. Minerals containing $\mathrm{Ag}_{\text {metallic }}, \mathrm{Fe}^{3+}, \mathrm{Mn}^{2+}, \mathrm{Pb}_{3}\left(\mathrm{PO}_{4}\right)_{2}$ and $\mathrm{PbHPO}_{4}$ were found in a precipitated state. The ionic strength in solution for samples of profiles A and B varied from $2.198^{-3}$ to $3.755^{-3}$ and from $2.662^{-3}$ to $7.777^{-3}$, respectively.

\begin{tabular}{|c|c|c|c|c|c|}
\hline \multirow{3}{*}{ Sample } & \multicolumn{5}{|c|}{ Mineral species (\%) } \\
\hline & Quartz & Orthoclase & Kaolinite & Calcite & Ferrosilite \\
\hline & $\mathrm{SiO}_{2}$ & $(\mathrm{~K}, \mathrm{Na}) \mathrm{AlSi}_{3} \mathrm{O}_{8}$ & $\mathrm{Al}_{2} \mathrm{O}_{3} \cdot 2 \mathrm{SiO}_{2} \cdot 2 \mathrm{H}_{2} \mathrm{O}$ & $\mathrm{CaCO}_{3}$ & $\mathrm{Fe}_{2} \mathrm{Si}_{2} \mathrm{O}_{3}$ \\
\hline \multicolumn{6}{|c|}{ PROFILE A } \\
\hline $1 \mathrm{~A}$ & 83.3 & 6.8 & 4.4 & & 5.5 \\
\hline $2 \mathrm{~A}$ & 78.9 & 9.7 & 2.4 & & 8.9 \\
\hline $7 \mathrm{~A}$ & 85.8 & 9.2 & 4.9 & & \\
\hline $16 \mathrm{~A}$ & 81.49 & 6.10 & 10.08 & 2.33 & \\
\hline $17 \mathrm{~A}$ & 84.75 & 10.8 & 3.61 & 0.84 & \\
\hline $23 \mathrm{~A}$ & 77.3 & 20.5 & 2.2 & & \\
\hline $27 \mathrm{~A}$ & 81.26 & 7.14 & 6.51 & 5.10 & \\
\hline $33 \mathrm{~A}$ & 91.79 & 4.28 & 2.66 & 1.27 & \\
\hline $34 \mathrm{~A}$ & 82.03 & 9.85 & 7.02 & 1.10 & \\
\hline \multicolumn{6}{|c|}{ PROFILE B } \\
\hline 1B & 67.53 & 12.94 & 19.53 & & \\
\hline 2B & 76.5 & 9.5 & 14.0 & & \\
\hline $7 \mathrm{~B}$ & 58 & 27.2 & 11.4 & & 3.4 \\
\hline $10 \mathrm{~B}$ & 71.75 & 21.36 & 5.34 & 1.54 & \\
\hline
\end{tabular}

Blank cells indicate that the mineral species was not identified or was below the detection limit of the analytical equipment. 


\subsection{Risk for Human Exposure}

This risk determination defines the risk of contaminants entering the body via a variety of routes (i.e., via inhalation or oral ingestion of contaminated water). The magnitude, frequency and duration of the contact between human beings and the contaminant were estimated [39]. For this study, exposure to $\mathrm{Cr}^{6+}$ was assumed to principally occur via oral ingestion of contaminated water, as levels of this toxic contaminant in the leachates exceeded the MPL for drinking water. Table 4 summarizes the data used in calculations (Equation (3)) and the average daily dose for $\mathrm{Cr}^{6+}$ that an inhabitant of the city of Pachuca might consume: $1.45 \times 10^{-4} \mathrm{mg} / \mathrm{L} / \mathrm{day}$.

\section{Discussion}

The integration of the results obtained by different analyses and data from previous studies conducted in the area provides a general overview of the effect that the tailings from the Dos Carlos deposit can have on the environment and, consequently, on the population of Pachuca and its urban area.

\subsection{Physical Characteristics of the Tailings Deposit}

The tailings deposit is predominantly composed of fractions of fine sand, with some fractions of silt and clay. [40] suggests that there is a direct relationship between fine particle size and the ease with which particles release their minerals when they come in contact with atmospheric oxygen or water. Previous work [41] reports that minerals are released more easily in fractions with sizes of $70 \mu \mathrm{m}$ or less than in fractions with sizes greater than $70 \mu \mathrm{m}$. In contrast, studies carried out in a mining site in the State of Mexico [11] reported that mineral release occurred to the greatest extent in particulate fractions with sizes of $70 \mu \mathrm{m}$, which correspond to fine sands and represent the finest fraction observed in the tailings.

It is known that the greater the dilution imposed on the particle, the greater the separation efficiency of its chemical components [42]. Similar results were obtained in laboratory [43], observing that tailing particulates less than $1000 \mu \mathrm{m}$ in size had high levels of heavy metals. [44] used wet centrifugation and observed that the weight of the smallest particles in the tailings allowed the particles to more easily separate from sulfuric minerals; however, this separation occurred only in the fraction of fine sand.

The preceding discussion suggests that the fine sands of the Dos Carlos tailings are less likely to become saturated in water than the silt particles; however, mineral release is favored in both fractions (although to a lesser
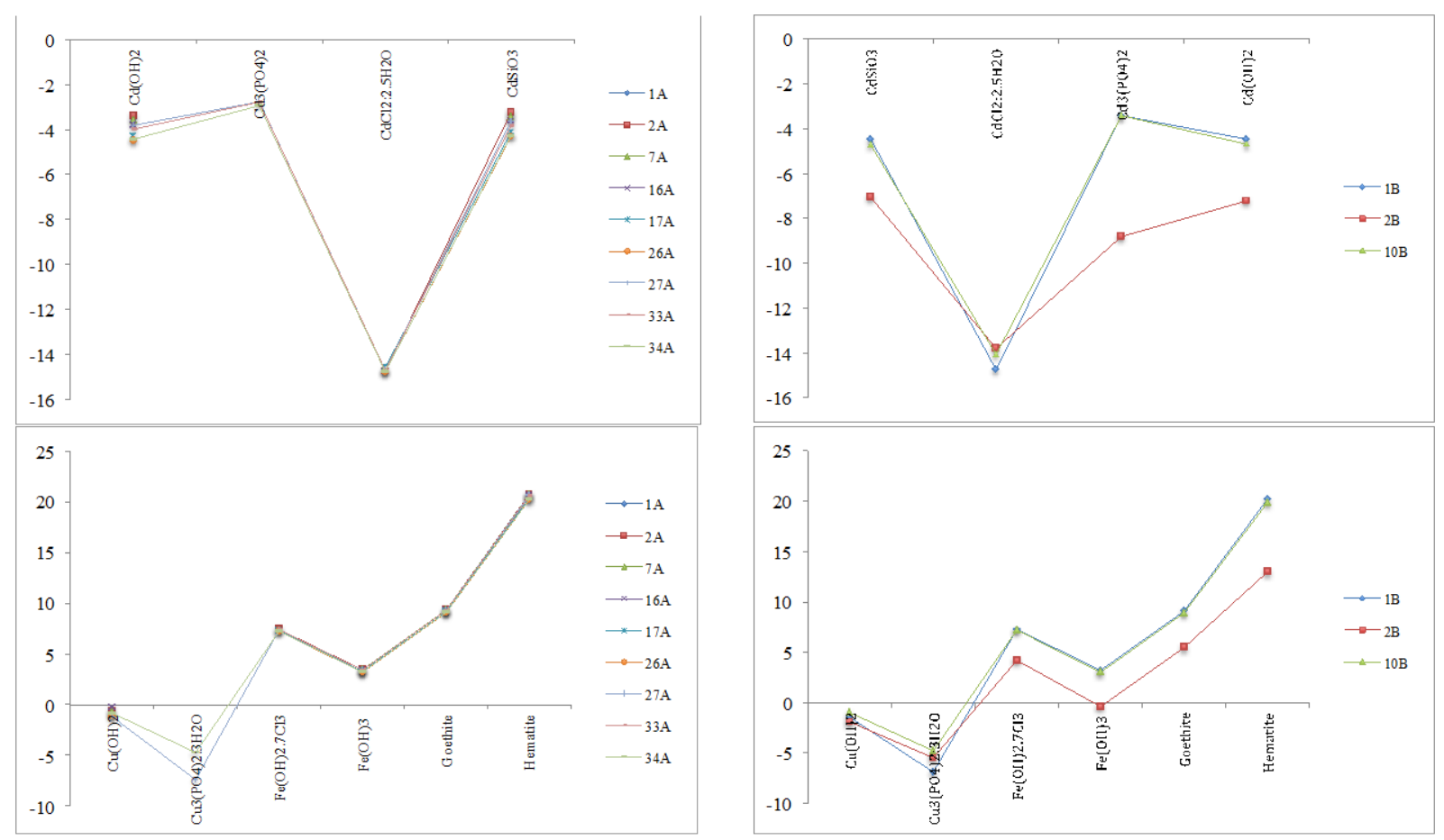

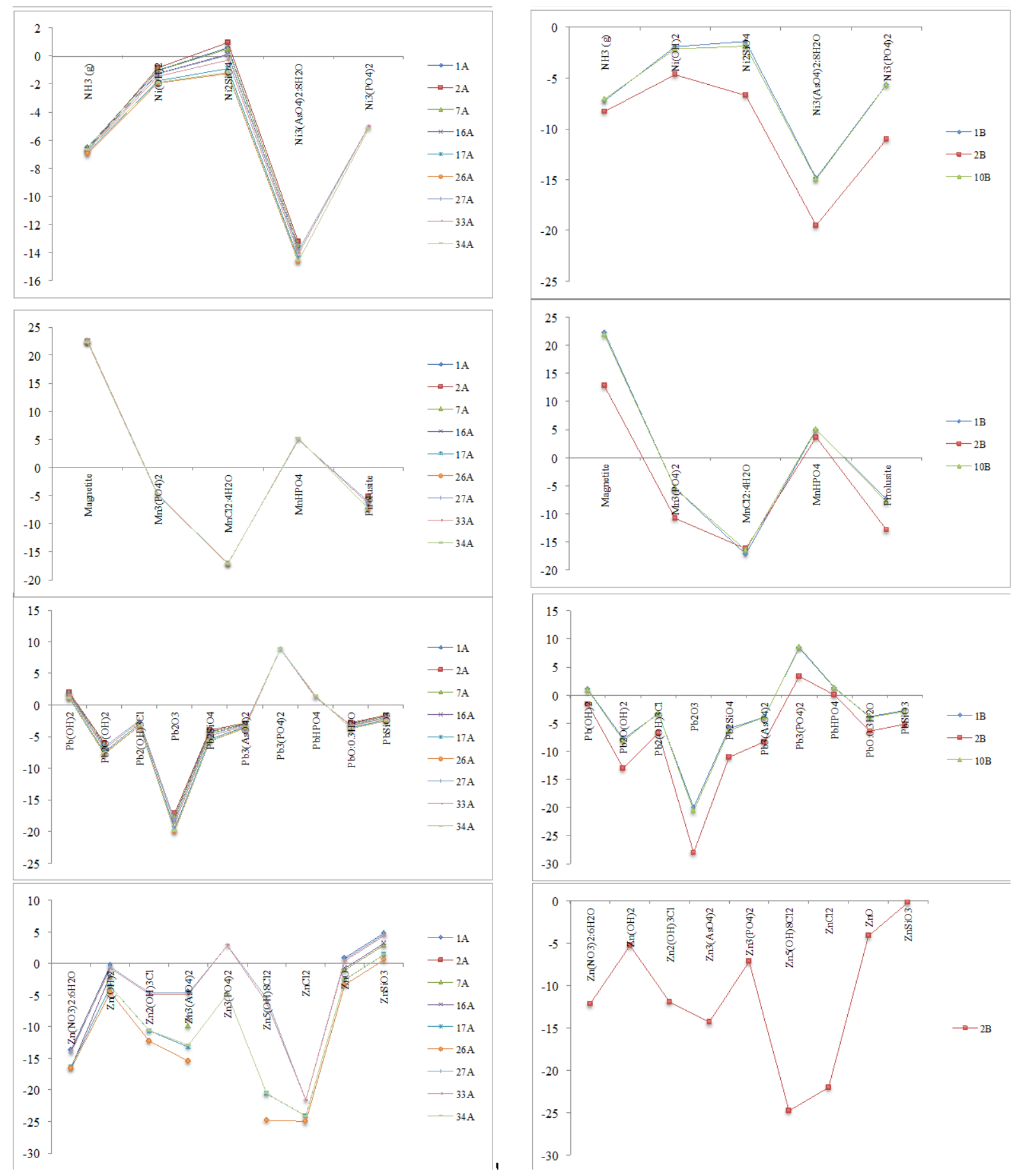

Figure 3. Geochemical speciation of selected minerals.

extent in the fraction of fine sands). This means that contaminants such as $\mathrm{Cr}^{6+}, \mathrm{NO}_{3}^{-}$and $\mathrm{NO}_{2}^{-}$could be released every time oxygen diffuses through the pores of the tailings. [45] showed that the reaction speed and effective diffusion of oxygen through the tailings are affected by factors such as the degree of saturation and the porosity of the material; more specifically, greater diffusion of oxygen throughout the pores occurs at lower degrees of saturation. The percent humidity encountered in the different horizons of both profiles was low $(1 \%$ 15\%); however, these values favor the leaching of certain minerals from mining activities. [46] indicated that when water infiltrates through this type of deposit, it acquires a similar chemical composition as the water con- 
Table 4. Exposure factors for an adult Mexican living near the tailings deposit.

\begin{tabular}{ccccc}
\hline Factor/Parameter & Symbol & Unit & Residential & Data source \\
\hline Concentration of the contaminant: $\mathrm{Cr}^{6+}$ & $\mathrm{C}$ & $\mathrm{mg} / \mathrm{L}$ & 0.014 & This study \\
Ingestion rate (Drinking water) & $\mathrm{IR}_{\mathrm{w}}$ & $\mathrm{L} / \mathrm{day}$ & 2.0 & {$[39]$} \\
Exposure Duration & $\mathrm{ED}$ & Years & 30 & {$[56]$} \\
Exposure Frequency & $\mathrm{EF}$ & Days/year & 365 & {$[56]$} \\
Body Weight & $\mathrm{BW}$ & $\mathrm{Kg}$ & 74.8 & {$[36]$} \\
Averaging Time & $\mathrm{AT}$ & Years & 77 & {$[36]$} \\
\hline
\end{tabular}

tained in the host rock. This type of leaching into the Dos Carlos deposit was reflected in the slightly acidic horizons ( $\mathrm{pH}$ values of 5.93 to 6.83) where evidence of the oxidation of iron sulfides was observed.

\subsection{Chemistry of the Tailings Deposit}

Chemical analyses of the tailings deposit identified the presence of $\mathrm{Cr}^{6+}, \mathrm{NO}_{3}^{-}, \mathrm{NO}_{2}^{-}$[28]-[32]; levels of these contaminants were two, three and up to 14 times higher, respectively, than the maximum permissible limits (Tables 2(a) and (b)).

An analysis of leachates from eight samples collected on the surface (first $50 \mathrm{~cm}$ ) of the Dos Carlos tailings [18] reported levels of $\mathrm{Cu}^{+}$(maximum $=1.045 \mathrm{mg} / \mathrm{L}$; average $=0.43 \mathrm{mg} / \mathrm{L}$ ), $\mathrm{Cd}^{2+}$ (maximum $=0.625 \mathrm{mg} / \mathrm{L}$; average $=0.244 \mathrm{mg} / \mathrm{L}), \mathrm{Fe}^{3+}($ maximum $=4.16 \mathrm{mg} / \mathrm{L} ;$ average $=1.07 \mathrm{mg} / \mathrm{L}), \mathrm{Mn}^{2+}($ maximum $=53.55 \mathrm{mg} / \mathrm{L} ; \mathrm{av}-$ erage $=29.83 \mathrm{mg} / \mathrm{L}), \mathrm{Pb}^{2+}($ maximum $=1.685 \mathrm{mg} / \mathrm{L}$; average $=0.8 \mathrm{mg} / \mathrm{L}), \mathrm{Ag}($ maximum $=0.41 \mathrm{mg} / \mathrm{L}$; average $=0.12 \mathrm{mg} / \mathrm{L}$ ) and $\mathrm{Ni}^{2+}$ (maximum $=0.6 \mathrm{mg} / \mathrm{L}$; average $=0.12 \mathrm{mg} / \mathrm{L}$ ). This analysis concluded that the tailings of the Dos Carlos deposit are potential sources of acid mine drainage [18]. The values obtained in this study were compared with the values obtained by [18] and with the standards established [28]-[32]. Two, eight, three, eight, five, one and three samples had levels of $\mathrm{Cu}^{+}, \mathrm{Cd}^{2+}, \mathrm{Fe}^{3+}, \mathrm{Mn}^{2+}, \mathrm{Pb}^{2+}, \mathrm{Ag}$ and $\mathrm{Ni}^{2+}$, respectively, that exceeded the MPLs [30] [31].

When the leachates mix with ground water, the concentrations of pollutants are diluted in the new water body, resulting in pollutant levels that are only slightly higher than the MPLs; consequently, the risk of compromising the water quality is negligible or nonexistent. However, for ions with levels that were several-fold higher than the MPL (as in the case of $\mathrm{Cd}^{2+}$ ), the risk is greater. $\mathrm{Cd}^{2+}$ in particular should be given special attention, as this ion can be a gastric irritant and can cause vomiting and diarrhea in humans. In some short-term studies, the oral administration of soluble Ni to animals resulted in the accumulation of this compound in the kidneys, lungs, liver and heart (in that order), and absorption via the lungs resulted in toxicity and carcinogenicity [47].

The particulates in the tailings were observed to influence the chemical composition of the soil in the metropolitan area of Pachuca. [48] reported $\mathrm{Cu}^{+}$concentrations of $34.68-119.88 \mathrm{mg} / \mathrm{kg}$ and $\mathrm{Cd}^{2+}$ concentrations of $0.13-20.07 \mathrm{mg} / \mathrm{kg}$ in the soil around Pachuca; the authors concluded that the presence of these elements was associated with activities of the Mining District Pachuca-Real del Monte and that these compounds may have come from the Dos Carlos tailings. In contrast, these authors concluded that the concentrations of $\mathrm{Mn}^{2+}(188$ $780 \mathrm{mg} / \mathrm{kg}$ ) and $\mathrm{Pb}^{2+}(9.64$ - $114.6 \mathrm{mg} / \mathrm{kg})$ were associated with atmospheric emissions produced by vehicles. However, the possibility that these elements could also come from the Dos Carlos tailings should not be excluded. In this context, performing atmospheric measurements to estimate the wind-borne spread of some of the ions from the tailings will be critical, as, for example, manganese can affect the nervous system in humans and cause deleterious neurological effects [49].

As shown in the correlation matrix of the physico-chemical parameters measured in this study (Table 5), strong positive correlations $\left(\mathrm{r}^{2}>0.50\right)$ were observed for the following pairs in the indicated order: $\mathrm{pH}$ and E.C. > Eh, $\mathrm{Cu}^{+}$and $\mathrm{Zn}^{2+}>$ E.C. $>\mathrm{pH}, \mathrm{NO}_{3}^{-}$and $\mathrm{NO}_{2}^{-}$, and vice versa. These correlations indicate that variations in the $\mathrm{pH}$ of the leachates could contribute to the dissolution or precipitation of ions, thereby producing a more acidic or neutral-alkaline environment, respectively. The correlation between $\mathrm{Cu}^{+}$and $\mathrm{Zn}^{2+}$ is related to the type of deposit exploited; therefore, as the $\mathrm{pH}$ decreases, these ions will continue to be released. The presence of $\mathrm{NO}_{3}^{-}$can be related with agriculture soil eroded that was deposited by aeolian transportation; other source for nitrates can be associated with atmospheric emissions produced by vehicles [48]. 
Table 5. Cross correlation matrix of physico-chemical parameters of the tailings deposit.

\begin{tabular}{cccccccccccc}
\hline & $\mathbf{p H}$ & $\mathbf{E h}$ & $\mathbf{E . C .}$ & $\mathbf{C r}^{6+}$ & $\mathbf{C u}^{+}$ & $\mathbf{N O}_{3}^{-}$ & $\mathbf{N O}_{2}^{-}$ & $\mathbf{P O}_{4}^{3-}$ & $\mathbf{P}^{+}$ & $\mathbf{S i O}_{2}$ & $\mathbf{Z n}^{2+}$ \\
\hline $\mathbf{p H}$ & 1.00 & & & & & & & & & & \\
$\mathbf{E h}$ & $\mathbf{0 . 5 3}$ & 1.00 & & & & & & & & & \\
$\mathbf{E . C .}$ & $\mathbf{0 . 6 7}$ & $\mathbf{0 . 6 8}$ & 1.00 & & & & & & & \\
$\mathbf{C r}^{6+}$ & 0.47 & 0.31 & -0.03 & 1.00 & & & & & & \\
$\mathbf{C u}^{+}$ & 0.21 & $\mathbf{0 . 5 5}$ & $\mathbf{0 . 7 0}$ & -0.23 & 1.00 & & & & & \\
$\mathbf{N O}_{3}^{-}$ & 0.14 & -0.11 & -0.04 & 0.09 & -0.19 & 1.00 & & & & & \\
$\mathbf{N O}_{2}^{-}$ & -0.39 & -0.24 & -0.10 & -0.42 & 0.13 & $\mathbf{0 . 6 2}$ & 1.00 & & & & \\
$\mathbf{P O}_{4}^{3-}$ & -0.64 & -0.37 & -0.75 & 0.13 & -0.38 & -0.03 & 0.16 & 1.00 & & & \\
$\mathbf{P}^{+}$ & -0.60 & -0.40 & -0.69 & -0.03 & -0.46 & 0.31 & 0.22 & $\mathbf{0 . 7 4}$ & 1.00 & & \\
$\mathbf{S i O}_{2}$ & 0.14 & 0.43 & 0.26 & 0.29 & 0.27 & -0.46 & -0.34 & -0.08 & -0.46 & 1.00 & \\
$\mathbf{Z n}^{2+}$ & 0.27 & $\mathbf{0 . 6 5}$ & $\mathbf{0 . 7 8}$ & -0.12 & $\mathbf{0 . 9 6}$ & -0.22 & 0.00 & -0.34 & -0.48 & 0.36 & 1.00 \\
\hline
\end{tabular}

\subsection{Mineralogy and Speciation}

The mineralogical analysis of the Dos Carlos tailings and the comparison of mineral speciation results in profiles $\mathrm{A}$ and $\mathrm{B}$ suggest that minerals in a state of dissolution are releasing $\mathrm{Ag}$ metallic, $\mathrm{Cd}^{2+}, \mathrm{Cu}^{+}, \mathrm{Ni}^{2+}, \mathrm{Pb}^{2+}$ and $\mathrm{Zn}^{2+}$ into the environment. Minerals that contain $\mathrm{Fe}^{3+}, \mathrm{Ag}_{\text {metallic }}, \mathrm{Pb}(\mathrm{OH})_{3}, \mathrm{ZnSiO}_{3}$ and $\mathrm{ZnO}$ are found in a precipitated state. This indicates that certain minerals such as quartz, calcite and kaolinite could promote an atmosphere in which low levels of acidity in the deposit can be neutralized [50]. [51] stated that the interaction of calcite with fluids that contain phosphate in slightly acidic to slightly alkaline environments results in the dissolution of calcite and promotes the precipitation of Ca-phosphate phases. In contrast, [52] determined the acidity constants of several clays and found that the kaolinite group favors the retention of heavy metals. The mobility of certain ions in the soil could also influence the mobilization of the dissolved ions; for example, $\mathrm{Pb}^{2+}$ has negligible mobility in soils (or tailings) with a slightly alkaline $\mathrm{pH}$, whereas $\mathrm{Cu}^{+}$and $\mathrm{Zn}^{2+}$ have greater mobility in this type of soil [53].

Minerals in the tailings such as kaolinite and calcite that are found at high concentrations could neutralize the dissolution of minerals containing $\mathrm{Cu}^{+}, \mathrm{Cr}^{6+}$, and $\mathrm{Zn}^{2+}$. [54] reported that when the $\mathrm{pH}$ is almost neutral (6.5 - 7), the neutralization of calcite occurs as follows: $\mathrm{CaCO}_{3}+2 \mathrm{H}^{+}=\mathrm{Ca}^{2+}+\mathrm{CO}_{2}+\mathrm{H}_{2} \mathrm{O}$. However, it is necessary to conduct other studies to determine the neutralization capacity of these minerals in this deposit.

\subsection{Oral Exposure of $\mathrm{Cr}^{6+}$}

The mean daily dose of $\mathrm{Cr}^{6+}$ in groundwater (the main source of water for the population) that an inhabitant of the study area could safely consume is $1.45 \times 10^{-4} \mathrm{mg} / \mathrm{L} / \mathrm{d}$. The carcinogenic potential of chrome ingested orally has not yet been determined. It has been determined that inhabitants of a village in China who consumed drinking water with $20 \mathrm{ppm}$ of this contaminant suffered adverse health effects [55]. However, in a toxicological review of hexavalent chromium, the [56] reported that $5 \%$ of orally ingested $\mathrm{Cr}^{6+}$ is absorbed by the gastrointestinal track. Once transported into the bloodstream, a portion of this concentration can remain in the body for a long time without causing apparent damage.

\section{Conclusions}

This preliminary study showed that the granulometric fraction of tailings with fine sand and a lower percentage of silts and clays favors the diffusion of oxygen (atmospheric or from water infiltration). This finding was confirmed by the fact that both profiles had moisture contents that could promote the oxidation of minerals, especially in the horizons with a slightly acidic $\mathrm{pH}$. $\mathrm{Cr}^{6+}, \mathrm{NO}_{3}^{-}$and $\mathrm{NO}_{2}^{-}$were found at different depths in contaminant levels. A correlation matrix showed that the behaviors of the physical and chemical parameters of the 
tailings were strongly related. This indicates that the environmental conditions (diffusion of atmospheric oxygen or rainfall) affect the physico-chemical composition of the tailings. In addition, the origin of the deposit, the mining activities and the mineral separation that occur during the mining process also influence the chemical composition of the tailings. Therefore, the concentrations of the previously mentioned elements vary with $\mathrm{pH}$ and with the diffusion of oxygen through the pores of the tailings.

The analysis of the geochemical modeling showed that minerals containing ions characteristic of acid mine drainage were dissolved in both profiles, as it was also reported in a previous study. In contrast, minerals such as calcite and kaolinite were observed to be capable of being neutralized.

The above-mentioned findings and the concentrations of $\mathrm{Cr}^{6+}$ measured in the leachates from the tailings suggest that the oral ingestion of this $\mathrm{Cr}^{6+}$ mixed with groundwater should not cause adverse health effects. However, it is necessary to investigate the mean daily dose that the population currently ingests through inhalation. Therefore, the infiltration of leachates of the tailings into the groundwater and the wind-borne transport of contaminants from the tailings' deposit present a potential risk of contamination to the environment and human population. However, a detailed chemical and atmospheric analysis is necessary to definitively confirm whether this deposit is the source of short-term contamination of the environment and the health of the population.

\section{Acknowledgements}

The authors are grateful to the Faculty Improvement Program (PROMEP) for financing through the project F-PROMEP-38/Rev-03, SEP-23-005. We also thank to the Biotechnology and Environmental Microbiology Research Group for their helpful comments.

\section{References}

[1] Martín-Romero, F. (2004) Procesos geoquímicos que controlan la movilidad en metales y metaloides en jales de sulfuros metálicos "El Fraile”, Taxco-Guerrero: México, D.F.,[Geochemical Processes That Control Mobility in Metals and Non-Metals in the Metallic Sulfide Tailings of "El Fraile”, Taxco-Guerrero: Mexico, D.F]. Universidad Nacional Autónoma de México, Instituto de Geofísica, Tesis de Doctorado, 200 p.

[2] Méndez-Ramírez, M. and Armienta-Hernández, M.A. (2012) Distribución de Fe, Zn, Pb, Cu, Cd y As originada por residuos mineros y aguas residuales en un transecto del Río Taxco en Guerrero, México [Distribution of $\mathrm{Fe}, \mathrm{Zn}, \mathrm{Pb}, \mathrm{Cu}$, $\mathrm{Cd}$, and As Caused by Mining Waste and Wastewater in a Transect of the Taxco River in Guerrero, Mexico]. Revista Mexicana de Ciencias Geológicas, 29, 450-462.

[3] Ruiz-Huerta, E.A. and Armienta-Hernández, M.A. (2012) Acumulación de arsénico y metales pesados en maíz en suelos cercanos a jales o residuos mineros [Accumulation of Arsenic and Heavy Metals in Corn in Soils near Tailings or Mining Waste]. Revista Internacional de Contaminación Ambiental, 28, 103-117.

[4] García-Meza, J.V., Ramos, E., Carrillo-Chávez, A. and Durán-de-Bazúa, C. (2004) Mineralogical and Chemical Characterization of Historical Mine Tailings from the Valenciana Mine, Guanajuato, Mexico: Environmental Implications. Bulletin of Environmental Contamination and Toxicology, 72, 170-177. http://dx.doi.org/10.1007/s00128-003-0256-1

[5] Morton-Bermea, O., Carrillo-Chávez, A., Hernández, E., González-Partida, E. (2004) Determination of Metals for Leaching Experiments of Mine Tailings: Evaluation of the Potential Environmental Hazard in the Guanajuato Mining District, Mexico. Bulletin of Environmental Contamination and Toxicology, 73, 770-776. http://dx.doi.org/10.1007/s00128-004-0492-z

[6] Mendoza-Amézquita, E., Armienta-Hernández, M.A., Ayora, C., Soler, A. and Ramos-Ramírez, E. (2006) Potencial de lixiviación de elementos traza en jales de las minas La Asunción y Las Torres, en el Distrito Minero de Guanajuato, México [Leaching Potential of Trace Elements in Mine Tailings of the La Asunción and Las Torres Mines in the Mining District of Guanajuato, Mexico]. Revista Mexicana de Ciencias Geológicas, 23, 75-83.

[7] Ramos-Arroyo, Y.R. and Siebe-Grabach, C.D. (2006) Estrategia para identificar jales con potencial de riesgo ambiental en un distrito minero: estudio de caso en el Distrito de Guanajuato, México [Strategy for Identifying the Environmental Risk of Tailings in a Mining District: A Case Study in the District of Guanajuato, Mexico]. Revista Mexicana de Ciencias Geológicas, 23, 54-74.

[8] Gutiérrez-Ruiz, M., Romero, F.M. and González-Hernández, G. (2007) Soils and Sediments Affected by the Dispersion of Metal Sulfide from Inactive Tailings in the Santa Barbara Mining Area, Chihuahua, México. Revista Mexicana de Ciencias Geológicas, 24, 170-184.

[9] González-Sandoval, M.R., Sánchez-Tovar, S., Márquez-Herrera, C., Lizárraga-Mendiola, L. and Durán-Domínguez, M.C. (2008) Oxidación de jales ricos en pirita en un reactor a escala de banco [Oxidation of Pyrite-Rich Tailings in a Bench Scale Reactor]. Edición Especial de la Revista Latinoamericana de Recursos Naturales, 4, 130-138. 
[10] Lizárraga-Mendiola, L., Durán-Domínguez, M.C. and González-Sandoval, M.R. (2008) Environmental Assessment of an Active Tailings Pile in the State of Mexico (Central Mexico). Research Journal of Environmental Sciences, 2, 197208. http://dx.doi.org/10.3923/rjes.2008.197.208

[11] Lizárraga-Mendiola, L., González-Sandoval, M.R., Durán-Domínguez, M.C. and Márquez-Herrera, C. (2009) Geochemical Behavior of Heavy Metals in a Zn-Pb-Cu Mining Area in the State of Mexico (Central Mexico). Environmental Monitoring and Assessment, 155, 355-372. http://dx.doi.org/10.1007/s10661-008-0440-1

[12] Luna-Celis, L., Martín-Romero, F., Villaseñor-Cabral, M.G. and Gutiérrez-Ruíz, M. (2008) Mineralogía y geoquímica de los jales de la Unidad Minera Charcas, San Luis Potosí [Mineralogy and Geochemistry of the Tailings from the Charcas Mining Unit, San Luis Potosí]. Boletín de Mineralogía, 18, 57-58.

[13] Méndez, M. and Armienta, M.A. (2003) Arsenic Phase Distribution in Zimapán Mine Tailings, Mexico. Geofísica Internacional, 42, 131-140.

[14] Asociación de Ingenieros de Minas, Metalurgistas y Geólogos de México (AIMMGM) (1961) La planta de beneficio de los jales de la Comisión del Fomento Minero en Santa Julia, Pachuca, Hidalgo[The processing plant of the tailings of the Fomento Mining Commission at Santa Julia, Pachuca, Hidalgo]. Gto., Memoria de la IV Convención Nacional de la AIMMGM, Guanajuato.

[15] Soto-Oliver, N. (1982) La minería: el distrito minero Pachuca-Real del Monte a través de la historia. Pachuca de Soto, México [Mining: The Pachuca-Real del Monte Mining District throughout History. Pachuca de Soto, Mexico]. Gobierno del Estado de Hidalgo, Coordinación de Turismo, Cultura y Recreación.

[16] Comisión de Fomento Minero (CFM) (1959) Planta de Tratamiento de Jales Unidad “Santa Julia”, Pachuca, Hidalgo [Tailings Treatment Plant of the "Santa Julia” Unit, Pachuca, Hidalgo]. Boletín Núm, México, D.F., 6.

[17] Geyne, A.R., Fries Jr., C., Segerstrom, K., Black, R.F. and Wilson, I.F. (1963) Geology and Mineral Deposits of the Pachuca-Real del Monte District, State of Hidalgo, México. Consejo de Recursos Minerales, México, D.F., Publicación 5E.

[18] Moreno-Tovar, R. (2006) Evaluación geoquímico ambiental de residuos (jales) de mineralizaciones polimetálicas del Estado de Hidalgo, México [Environmental Geochemical Assessment of Waste (Tailings) of Polymetallic Mineralization of the State of Hidalgo, Mexico]. Universidad Autónoma de San Luis Potosí, Facultad de Ingeniería, Tesis de Doctorado.

[19] Hernández-Ávila, J. (2009) Cinética de molienda y recuperación de Ag mediante procesos convencionales y no convencionales de las escombreras de la industria minero-metalúrgica del estado de Hidalgo [Kinetics of Milling and Recovery of Ag by Means of Conventional and Non-Conventional Processes from Slurries from the Mining-Metallurgical Industry of the State of Hidalgo]. Hidalgo, México, Universidad Autónoma del Estado de Hidalgo, Tesis de Doctorado, $150 \mathrm{p}$.

[20] Hernández-Acosta, E., Mondragón, R.E., Cristobal, A.D., Rubiños, P.J.E. and Robledo, S.E. (2009) Vegetación, residuos de mina y elementos potencialmente tóxicos de un jal de Pachuca, Hidalgo, México [Vegetation, Mine Waste and Potentially Toxic Elements of Tailings from Pachuca, Hidalgo, Mexico]. Revista Chapingo Serie Ciencias Forestales y del Ambiente, 15, 109-114.

[21] Koeppen, W. (1936) Das geographische System der Klimate, Handbuch der Klimatologie [The Geographical System of the Climate, Handbook of Climatology]. Borntraeger, Berlin, Bd. 1, Teil. C.

[22] García-de-Miranda, E. (1985) Apuntes de climatología: México, D.F. [Notes on Climatology: Mexico, D.F.]. Universidad Nacional Autónoma de México, Instituto de Geografía, 89 p.

[23] Servicio Meteorológico Nacional (SMN) (2012) Registro del Pronóstico del Tiempo [Record of the Weather Forecast]. Comisión Nacional del Agua, México, D.F. http://smn.cna.gob.mx

[24] Salas, G.P. (1975) Carta y provincias metalogenéticas de la República Mexicana [Map and Metallogenetic Provinces of Mexico]. México, D.F., Consejo de Recursos Minerales, 21E.

[25] Dreier, J.E. (2005) The Environment of Vein Formation and Ore Deposition in the Purisima-Colon Vein System, Pachuca Real del Monte District, Hidalgo, Mexico. Economic Geology, 100, 1325-1347.

http://dx.doi.org/10.2113/gsecongeo.100.7.1325

[26] Secretaría de Medio Ambiente y Recursos Naturales (SEMARNAT) (2004) Norma Oficial Mexicana que establece el procedimiento para caracterizar los jales, así como las especificaciones y criterios para la caracterización y preparación del sitio, proyecto, construcción, operación y postoperación de presas de jales [Official Mexican Standards that establish the procedure for characterizing tailings, and the specifications and criteria for the characterization and preparation of the site, project, construction, operation and post-operation of tailings dams] (NOM-141-SEMARNAT-2003). Diario Oficial de la Federación, México, D.F., 13 de septiembre de 2004, 54 p.

[27] Secretaría de Comercio y Fomento Industrial (SCFI) (2006) Norma Oficial Mexicana. Muestreo de suelos para la identificación y la cuantificación de metales y metaloides, entendiendo por éstos el arsénico, berilio, cadmio, cromo hex- 
avalente, mercurio, níquel, plomo, selenio, talio y vanadio [Soil Sampling for the Identification and Quantification of Metals and Metalloids Including Arsenic, Beryllium, Cadmium, Hexavalent Chromium, Mercury, Nickel, Lead, Selenium, Thallium and Vanadium] (NOM-AA-132-SCFI-2006). Diario Oficial de la Federación, 6 de marzo de 2006, México, D.F., 2 p.

[28] Secretaría de Medio Ambiente y Recursos Naturales (SEMARNAT) (2006) Norma Oficial Mexicana, que establece las características, el procedimiento de identificación, clasificación y los listados de los residuos peligrosos [Official Mexican Standards that Establish the Procedure for the Identification, Classification and Listing of Hazardous Waste], (NOM-052-SEMARNAT-2005). Diario Oficial de la Federación, 23 de junio de 2006, México, D.F., 22 p.

[29] Secretaría de Salud (SSA) (2000) Norma Oficial Mexicana. Salud ambiental. Agua para uso y consumo humano. Límites permisibles de calidad y tratamientos a que debe someterse el agua para su potabilización [Official Mexican Standards. Environmental health. Water for Human Consumption and Use. Permissible Limits of Quality and Necessary Treatment of the Water for Its Potability] (NOM-127-SSA1-1994). Diario Oficial de la Federación, 22 de noviembre del 2000, México, D.F., 10 p.

[30] United States Environmental Protection Agency (US EPA) (2009) National Primary Drinking Water Regulations. Washington DC, EPA 816-F-09-004. http://water.epa.gov/drink/contaminants/upload/mcl.pdf

[31] World Health Organization (WHO). (2011) Guidelines for Drinking-Water Quality. World Health Organization (WHO), Geneva, 564p.

[32] Secretaría de Medio Ambiente y Recursos Naturales (SEMARNAT). (1997) Norma Oficial Mexicana que establece los límites máximos permisibles de contaminantes en las descargas de aguas residuales en aguas y bienes nacionales [Official Mexican Standard that Establishes Maximum Permissible Limits of Pollutants in Wastewater Discharged into Water and National Property] (NOM-001-SEMARNAT-1996). Diario Oficial de la Federación, 6 de enero de 1997, México, D.F., 35p.

[33] Parkhurst, D.L. and Appelo, C.A.J. (1999) User's Guide to PHREEQC (Version 2)—A Computer Program for Speciation, Batch-Reaction, One-Dimensional Transport, and Inverse Geochemical Calculations. U.S. Geological Survey, Water Resources Investigations Report 99-4259, Washington DC.

[34] Ball, J.W. and Nordstrom, D.K. (1991) User's Manual for WATEQ4F, with Revised Thermodynamic Data Base and Test Cases for Calculating Speciation of Major, Trace, and Redox Elements in Natural Waters. U.S. Geological Survey, Open-File Report 91-183, Washington DC, 189 p.

[35] Drever, J.I. (1988) The Geochemistry of Natural Water. 2nd Edition, Prentice Hall, New York, 437p.

[36] The World Bank. (2013) Life Expectancy at Birth, Total (Years). http://data.worldbank.org/indicator/SP.DYN.LE00.IN

[37] Mondragón-Romero, E. (2008) Caracterización de un jal de mina con fines de restauración ecológica en Pachuca, Hidalgo[Characterization of Mine Tailings for the Purpose of Ecological Restoration in Pachuca, Hidalgo]. Universidad Autónoma Chapingo, tesis de licenciatura, México, D.F., 43p.

[38] Hillier, S. (2000) Accurate Quantitative Analysis of Clay and Other Minerals in Sandstones by XRD: Comparison of a Rietveld and a Reference Intensity Ratio (RIR) Method and the Importance of Sample Preparation. Clay Minerals, 35, 291-302. http://dx.doi.org/10.1180/000985500546666

[39] Lee, J.S., Chon, H.T. and Kim, K.W. (2005) Human Risk Assessment of As, Cd, Cu and Zn in the Abandoned Metal Mine Site. Environmental Geochemistry and Health, 27, 185-191. http://dx.doi.org/10.1007/s10653-005-0131-6

[40] Fall, M., Benzaazoua, M. and Ouellet, S. (2005) Experimental Characterization of the Influence of Tailings Fineness and Density on the Quality of Cemented Paste Backfill. Minerals Engineering, 18, 41-44.

[41] Wilber, W.G. and Hunter, J.V. (1979) The Impact of Urbanization on the Distribution of Heavy Metals in Bottom Sediments of the Saddle River. Water Resources Bulletin, 15, 790-800. http://dx.doi.org/10.1111/j.1752-1688.1979.tb00397.x

[42] Heiskanen, K. (1987) Classification Handbook. Larox, New York.

[43] Jopony, M., Usup, G. and Mohamed, M. (1987) Particle Size Distribution of Copper Mine Tailings from Lohan Ranau Sabah and Its Relationship with Heavy Metal Content. Pertanika, 10, 37-40.

[44] Paterson \& Cooke Ltd. (2011) Cycloning of Tailing for the Production of Sand as TSF Construction Material. Proceedings of Tailings and Mine Waste 2011, Vancouver, 6-9 November 2011, 11.

[45] Martin, V., Aubertin, M., Bussière, B., Mbonimpa, M., Dagenais, A.M. and Gosselin, M. (2006) Measurement of Oxygen Consumption and Diffusion in Exposed and Covered Reactive Mine Tailings (Poster). In: R. I. Barnhisel, Ed., The 7th International Conference on Acid Rock Drainage (ICARD), St. Louis, The American Society of Mining and Reclamation (ASMR), 26-30 March 2006.

[46] Akabzaa, T.M. and Yidana, S.M. (2012) An Integrated Approach to Environmental Risk Assessment of Cumulatively Impacted Drainage Basin from Mining Activities in Southwestern Ghana. Environmental Earth Sciences, 65, 291-312. 
http://dx.doi.org/10.1007/s12665-011-1090-0

[47] Das, K.K., Das, S.N. and Dhundasi, S.A. (2008) Nickel, Its Adverse Health Effects \& Oxidative Stress. Indian Journal of Medical Research, 128, 412-425.

[48] Jonathan, M.P., Jayaprakash, M., Srinivasalu, S., Roy, P.D., Thangadurai, N., Muthuraj, S. and Pitchaimani, V.S. (2010) Evaluation of Acid Leachable Trace Metals in Soils around a Five Centuries Old Mining District in Hidalgo, Central Mexico. Water, Air and Soil Pollution, 205, 227-236. http://dx.doi.org/10.1007/s11270-009-0068-y

[49] United States Environmental Protection Agency (US EPA). (2004) Drinking Water Health Advisory for Manganese. Prepared by U.S. Environmental Protection Agency Office of Water (4304T), Health and Ecological Criteria Division, 20460, Washington DC. http://www.epa.gov/safewater/

[50] Hakkou, R., Benzaazoua, M. and Bussière, B. (2008) Acid Mine Drainage at the Abandoned Kettara Mine (Morocco): 1. Environmental Characterization. Mine Water and the Environment, 27, 145-159. http://dx.doi.org/10.1007/s10230-008-0036-6

[51] Klasa, J., Ruiz-Agudo, E., Wang, L.J., Putnis, C.V., Valsami-Jones, E., Menneken, M. and Putnis, A. (2013) An Atomic Force Microscopy Study of the Dissolution of Calcite in the Presence of Phosphate Ions. Geochimica et Cosmochimica Acta, 117, 115-128. http://dx.doi.org/10.1016/j.gca.2013.03.025

[52] Liu, X., Lu, X., Sprik, M., Cheng, J., Jan-Meijer, E. and Want, R. (2013) Acidity of Edge Surface Sites of Montmorillonite and Kaolinite. Geochimica et Cosmochimica Acta, 117, 180-190. http://dx.doi.org/10.1016/j.gca.2013.04.008.

[53] Razo, I., Carrizales, L., Castro, J., Díaz-Barriga, F. and Monroy, M. (2004) Arsenic and Heavy Metal Pollution of Soil, Water and Sediments in a Semi-Arid Climate Mining Area in Mexico. Water, Air, and Soil Pollution, 152, 129-152. http://dx.doi.org/10.1023/B:WATE.0000015350.14520.c1

[54] Dold, B. (2005) Basic Concepts of Environmental Geochemistry of Sulfide Mine-Waste. XXIV Curso Latinoamericano de Metalogenia UNESCO-SEG, del 22 de agosto al 2 de septiembre de 2005, Lima, 36p.

[55] Zhang, J. and Li, X. (1987) Chromium Pollution of Soil and Water in Jinzhou. Chinese Journal of Preventive Medicine, 21, 262-264.

[56] United States Environmental Protection Agency (US EPA). (1996) Proposed Guidelines for Carcinogen Risk Assessment. EPA/600/P-92/003C. Office of Research and Development, Washington DC. 